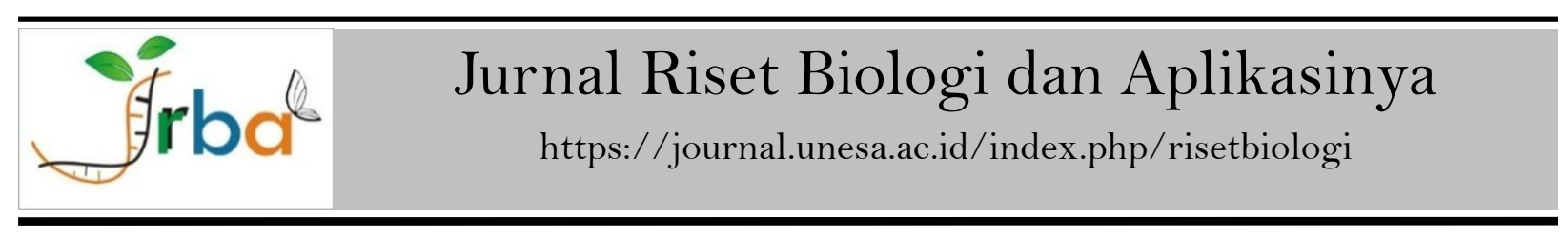

\title{
Effectiveness of Apu-Organic Liquid Fertilizer (Pistia stratiotes L.) on Ipomoea reptans Poir. Growth
}

\author{
Efektivitas Pupuk Organik Cair Apu-Apu (Pistia stratiotes L.) terhadap Pertumbuhan \\ Kangkung Darat (Ipomoea reptans Poir.)
}

\author{
Ambar Pratiwi*, Arni Isma Nurrohmi \\ Biology Study Program, Faculty of Applied Science and Technology, \\ Ahmad Dahlan University, Yogyakarta
}

\begin{abstract}
Article History
Received : 12 Februari 2020 Approved : 22 September 2020 Published: 30 September 2020

Keywords: Organic liquid fertilizer, growth, Ipmomoea reptans
\end{abstract}

Kata Kunci: Pupuk cair organik, pertumbuhan, Ipmomoea reptans

\begin{abstract}
Fertilization uses organic fertilizers made of Apu-apu (Pistia stratiotes L.) can support nutrient availability there by increasing soil fertility. $P$. stratiotes $\mathrm{L}$. contains nutrients but in elemental form that is not yet available. So far, the abundance of $P$. stratiotes $L$. has not been utilized properly by the society, hence that research is needed to make liquid organic fertilizer $P$. stratiotes L. by fermentation. The purpose of this study was to determine the increase in the growth of Ipomoea reptans Poir. by giving apu-apu liquid organic fertilizer and determine the optimum concentration of liquid organic fertilizer for apu-apu for the growth of ground water spinach. This research was conducted at the Kemusuh Green House, Banyurejo, Tempel, Sleman. The independent variable used was the POC concentration of Apu-apu plants with five replications and six levels of treatment $\left(\mathrm{K}=0 \%, \mathrm{P} 1=4 \%, \mathrm{P}_{2}=\right.$ $8 \%, \mathrm{P} 3=12 \%, \mathrm{P}_{4}=16 \%$ and $\left.\mathrm{P} 5=20 \%\right)$. The data obtained were analyzed using ANOVA followed by the Duncan Test. Apu-apu liquid organic fertilizer contains elements C (4.6\%), $\mathrm{N}(0.07 \%), \mathrm{P}(0.09 \%)$ and $\mathrm{K}(0.07 \%)$. The application of liquid organic fertilizer made from apu-apu has an effect on the growth of water spinach on the parameters of the number of leaves, leaves width, fresh weight and chlorophyll content. The conclusion obtained from the results of this study is that the application of liquid organic fertilizer apu-apu provides an increase in the growth of ground water spinach.
\end{abstract}

\begin{abstract}
Abstrak
Pemupukan dengan pupuk organik dari Apu-apu (Pistia stratiotes L.) dapat mendukung ketersediaan hara sehingga meningkatkan kesuburan tanah. P. stratiotes L. memiliki kandungan unsur hara namun dalam bentuk unsur yang belum tersedia. Kemelimpahan P. stratiotes L. selama ini belum dimanfaatkan dengan baik oleh masyarakat sehingga perlu adanya penelitian untuk menjadikan pupuk organik cair P. stratiotes L. dengan cara fermentasi. Tujuan penelitian ini adalah untuk menguji peningkatan pertumbuhan kangkung darat (Ipomoea reptans Poir.) dengan pemberian pupuk organik cair apu-apu dan menentukan konsentrasi pupuk organik cair apu-apu yang optimum untuk pertumbuhan kangkung darat. Penelitian ini dilaksanakan pada bulan April-Juni 2019 di Green House Kemusuh, Banyurejo, Tempel, Sleman. Variabel bebas yang digunakan adalah konsentrasi POC tanaman Apu-apu dengan 5 ulangan dan 6 taraf perlakuan $(K=0 \%, P 1=4 \%$, $\mathrm{P}_{2}=8 \%, \mathrm{P}_{3}=12 \%, \mathrm{P}_{4}=16 \%$ dan $\left.\mathrm{P}_{5}=20 \%\right)$. Data yang diperoleh dianalisis menggunakan ANOVA dan dilanjutkan dengan Duncan Test. Pupuk organik cair apu-apu mengandung unsur $C$ $(4,6 \%), N(0,07 \%), P(0,09 \%)$ dan K (0,07\%). Pemberian pupuk organik cair apu-apu memberikan pengaruh terhadap pertumbuhan kangkung darat pada parameter jumlah daun, luas daun, berat basah dan kadar klorofil. Kesimpulan yang diperoleh dari hasil penelitian ini adalah pemberian pupuk organik cair apu-apu memberikan peningkatan pertumbuhan kangkung darat.
\end{abstract}

How to cite: Pratiwi, A \& Nurrohmi, A.I. (2020). Effectiveness of Apu-Organic Liquid Fertilizer (Pistia stratiotes L.) on Ipomoea reptans Poir. Growth. Jurnal Riset Biologi dan Aplikasinya, 2(2), 55-63. 


\section{INTRODUCTION}

Farmers in Indonesia generally use inorganic fertilizers for cultivated crops. According to Noviyanti (2019), based on the results of the 2013 BPS agricultural census, the use of fertilizers was almost dominated by inorganic fertilizers, namely $86.41 \%$. The use of inorganic fertilizers if carried out continuously can affect the quality of a soil and can also reduce yields (Oviyanti \& Hidayah, 2016). One of the short comings of inorganic fertilizers is that they contain little or almost no micro-nutrients (Lingga \& Marsono, 2006). The continuous use of inorganic fertilizers causes a decrease in the soil organic matter content, the soil becomes solid (Sulaeman et al., 2016). Low micro-nutrients can lead to plants experiencing micronutrient deficiency, so they can experience growth and productivity barriers (Hayati, 2010). The way to get plant growth properly is by fertilizing using organic fertilizers. The use of organic fertilizers can increase soil productivity, crop yields and reduce the use of inorganic fertilizers (Sulaeman et al. $2017)$.

According to Oviyanti et al. (2016), a source of organic fertilizer from plants that has the potential to be used as liquid organic fertilizer is the gamal plant Gliricidia sepium (Jacq.) Kunth ex Walp. with the organ of the plant used, namely gamal leaves. The liquid organic fertilizer of gamal leaves with a concentration of $120 \mathrm{ml} / \mathrm{l}$ of water gave the most optimum effect on the vegetative growth of mustard plants. Another potential source of material for organic fertilizer is the apu-apu plant (Pistia stratiotes L.). Pistia stratiotes $\mathrm{L}$ has elements that are not yet available such as nitrogen, phosphate and potassium. According to Putri et al. (2013), Pistia stratiotes $\mathrm{L}$. has useful ingredients such as $\mathrm{N}: 2.83 \%$, P: $0.17 \%, \mathrm{~K}: 0.96 \%, \mathrm{C} / \mathrm{N}: 10$ and 47.020 organic matter so that Pistia stratiotes L. processed into liquid fertilizer.

Apu-apu plants are plants that grow wild and are included in the aquatic weed group (Baroroh et al.,2018). The distribution of P. stratiotes L. naturally can be found in subtropical and tropical areas (Rijal, 2014). Reproduction of P. stratiotes L. occurs very quickly, namely by removing the stolon. The presence of $P$. stratiotes L. in abundant rice fields can disrupt cultivated plants. Apu-apu abundance and high nitrogen content, and no research studies on the use of apu-apu as liquid organic fertilizer. This study examines the nutritional content of liquid organic fertilizer apu-apu and its effect on the growth of vegetable plants, especially kale.

Land spinach is a cultivated vegetable plant that is relatively familiar in Indonesia. The part of kale that is consumed is the leaves, it tastes fresh and contains iron, vitamins $\mathrm{A}, \mathrm{B}$ and $\mathrm{C}$ (Djuariah, 1997; Kusandriyani \& Luthfy, 2016). Kale also contains fiber and antioxidant compounds, which support the body's health (Edi \& Yusri, 2009). According to Handriatni (2010) the production of $I$. reptans Poir. influenced by nitrogen nutrients absorbed by plants. Nitrogen-deficient plants can be seen on the underside of usually older leaves starting to turn light green, then turning yellow. Leaves I. reptans Poir. In its growth, it is easy to turn yellow due to deficiency of nitrogen nutrients, so that alternative efforts are needed to improve the quality of leaves of $I$. reptans Poir. so that the productivity yields of $I$. reptans Poir. can increase. Therefore, it is necessary to make efforts to utilize $P$. stratiotes L. as a liquid organic fertilizer in this study.

This study aims to determine the growth of ground water spinach by applying apu-apu liquid organic fertilizer and to determine the optimum concentration of liquid organic fertilizer for the growth of ground water spinach.

\section{MATERIALS AND METHODS}

Apu-apu (Pistia stratiotes L.) was taken from the rice fields of Banyurejo, Tempel, Sleman. Apu-apu plants were washed, then dried in the sun for 30 minutes. Apu-apu was weighed as much as $2.1 \mathrm{~kg}$ (Oviyanti et al., 2016) then cut into small pieces. Apu-apu was put into a plastic jar filled with 3.2 liters of water, 5 grams of brown sugar and $21 \mathrm{ml}$ of $\mathrm{EM}_{4}$ (Oviyanti et al., 2016) then stirred until homogeneous. The jar was closed and left for 25 days. POC pH measurements were carried out twice, namely before the fermentation process and after the fermentation process, while the POC temperature was measured using a thermometer every 7 days. The liquid obtained was filtered using a filter and analyzed for the content of Carbon, Nitrogen, Phosphors, and Potassium.

$150 \mathrm{ml}$ of liquid fertilizer was given six times, namely $0,1,2,3,4$ and 5 weeks after planting (MST) with each plant receiving a concentration of O\%, $4 \%, 8 \%, 12 \%, 16 \%$ and $20 \%$ liquid fertilizer for apu-apu plants according to the assigned randomization design. 
Weeding and watering were conducted every 2 days. Measurement of humidity, temperature and light intensity was carried out every 7 days. Observation of stem height, number of leaves, and leaf area was carried out every 7 days. Observation of wet weight, dry weight and chlorophyll content test were carried out when kale plants were harvested.

The data analysis used in this study was the Analysis of Variance (ANOVA) with a 95\% confidence level, and then followed by Duncan test (Oviyanti et al., 2016).

\section{RESULTS AND DISCUSSION}

The organic fertilizer used is in the form of liquid organic fertilizer based on apu-apu (Pistia stratiotes L.) because it contains compounds that provide nutrients such as carbon, nitrogen, phosphorus and potassium. The process of making Pistia stratiotes L. fertilizer ends when there is a color change in the fertilizer material, from green to brownish yellow. In the process of fermentation of organic matter, microorganisms will work well if the conditions are right. The fermentation process will take place in semi anaerobic conditions, low $\mathrm{pH}$ (3-4), high salt and sugar levels, 30-40\% moderate water content, presence of fermentation microorganisms, and temperatures around $40-50^{\circ} \mathrm{C}$ (Indriani, 2002). The microorganisms contained in $\mathrm{EM}_{4}$ have a good effect on the quality of organic fertilizers, while the availability of nutrients in organic fertilizers is strongly influenced by the length of time it takes for bacteria to degrade waste (Amik \& Hardini, 2014).

The aroma of fertilizer produced after the fermentation process is in the form of alcoholic aroma. This can be caused because in $\mathrm{EM}_{4}$ contains Saccharomyces sp. where these microbes are able to convert glucose into alcohol and $\mathrm{CO}_{2}$. The initial acidity level of the fertilizer before fermentation is 7.1 and the final acidity after fermentation is 5.6. The degree of acidity as a minimum technical requirement for organic fertilizers ranges from 4-8 (Nur et al., 2016). The degree of acidity has decreased, which is in acidic conditions. Acidic conditions can occur due to the activity of bacteria that produce acid. The activity of Lactobacillus sp. which is present in $\mathrm{EM}_{4}$ converts carbohydrates into lactic acid (Puspadewi et al., 2011). The effect of the activity of Lactobacillus sp. causing the number of lactic acid bacteria to increase during the fermentation process followed by a decrease in $\mathrm{pH}$ environmental (Puspadewi et al., 2011).

The temperature of the fertilizer at the beginning of fermentation was $30^{\circ} \mathrm{C}$, while the temperature of the fertilizer when it was harvested decreased when compared to the initial temperature of the fermentation process, which was $28^{\circ} \mathrm{C}$. This is because at the end of fermentation the decomposition or respiration process has begun to decrease so that there is a decrease in the rate of reaction in producing energy so that the temperature decreases. The basic ingredients of the fertilizer have broken down in the fermenter, so that the activity and oxygen consumption decrease causing the temperature inside the fermenter to decrease. The results of the analysis of liquid organic fertilizer based on Pistia stratiotes L. are presented in Table 1.

The results of the analysis of Pistia stratiotes L. fertilizer nutrients (Table 1) show that the four nutrients have not met the POC quality standard according to the Regulation of the Minister of Agriculture Number 70/Permenten/SR.140/ 10/2011. The low nutrient content of the liquid organic fertilizer apu-apu can be caused by the incomplete anaerobic decomposition process. During the inorganic decomposition process, gases such as $\mathrm{CH}_{4}, \mathrm{CO}_{2}, \mathrm{~N}, \mathrm{CO}, \mathrm{O}$, ammonia are also produced, so that the nutrient content of liquid organic fertilizer is lower (Sulaeman et al., 2016).

Degradations microorganisms also need carbon compounds as their energy source for degradation of organic matter in the fermentation process, hence the resulting carbon content is low because it is converted to energy and gas (Jumirah, 2018).

Table 1. Analysis results of Pistia stratiotes L. liquid organic fertilizer.

\begin{tabular}{clccc}
\hline No & Parameter & Units & Results & Quality standards \\
\hline 1 & Carbon $(\mathrm{C})$ & $\%$ & 4,59705 & Minimum 6 \\
2 & Nitrogen $(\mathrm{N})$ & $\%$ & 0,06755 & $3-6$ \\
3 & Phosphor $(\mathrm{P})$ & $\%$ & 0,0949 & $3-6$ \\
4 & Potassium $(\mathrm{K})$ & $\%$ & 0,06845 & $3-6$ \\
\hline
\end{tabular}

Source: Chem-Mix Pratama Laboratory, 2019. 
Low nitrogen content can be caused by a change in the element nitrogen into gas (Jumirah, 2018). Low phosphorus levels occur because these elements are needed by microorganisms such as Lactobacillus sp, Saccharomyces sp, and molds as a macro source for their growth and development (Jumirah, 2018). The low levels of potassium are due to the basic ingredients of fertilizer consisting of high fiber content so that the decomposition process is not optimal (Jumirah et al., 2018).

Provision of Pistia liquid organic fertilizer can increase Ipomoea growth as indicated by the following parameters. The height of the stems increases due to the growth of the segments. This is due to the presence of cell division and cell elongation which is influenced by the auxin hormone as well as nutrient content, especially $\mathrm{N}$. Lingga \& Marsono (2003) stated that the main role of $\mathrm{N}$ is to accelerate overall growth, especially stems and leaves. The average height of the stems of ground water spinach (Ipomoea reptans Poir.) is presented in Figure 1.
Figure 1 shows that the highest average stem height of land spinach is obtained from treatment $16 \%$. The increase in stem height in plants treated with apu-apu liquid organic fertilizer is caused because the fertilizer contains nitrogen nutrients needed by plants for physiological processes, such as the phases of vegetative growth and metabolism in plants which will trigger plant growth and height (Oviyanti et al., 2016). The presence of $\mathrm{N}$ in organic fertilizers can support the synthesis of proteins and enzymes that support general growth, including the addition of plant height (Rahmah, at al., 2014). The presence of $\mathrm{P}, \mathrm{N}$ and $\mathrm{K}$ nutrients in the liquid organic fertilizer apu-apu plays a role in regulating growth. $\mathrm{N}$ and $\mathrm{K}$ nutrients support plant height increase because $K$ helps metabolize carbohydrates and accelerate the growth of meristematic tissue (Nyakpa et al., 1998). As for the results of observations on the height growth of Ipomoea reptans Poir stems. presented in Figure 2

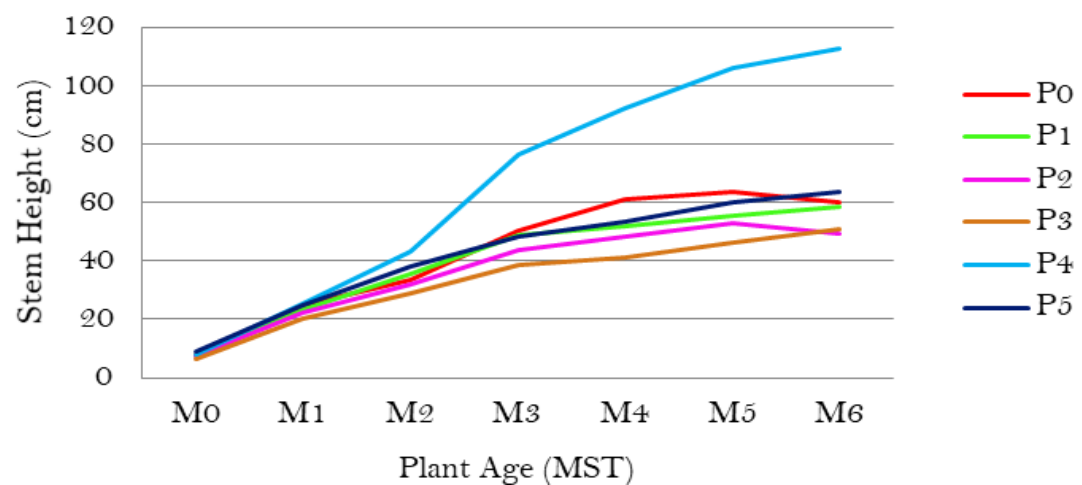

Figure 1. Average height of ground water spinach stems. Po: Control (without fertilizer) P1: Concentration 4\%; P2: Concentration 8\% P3: Concentration 12\%; P4: Concentration 16\% P5: Concentration 20\%; M: Week -

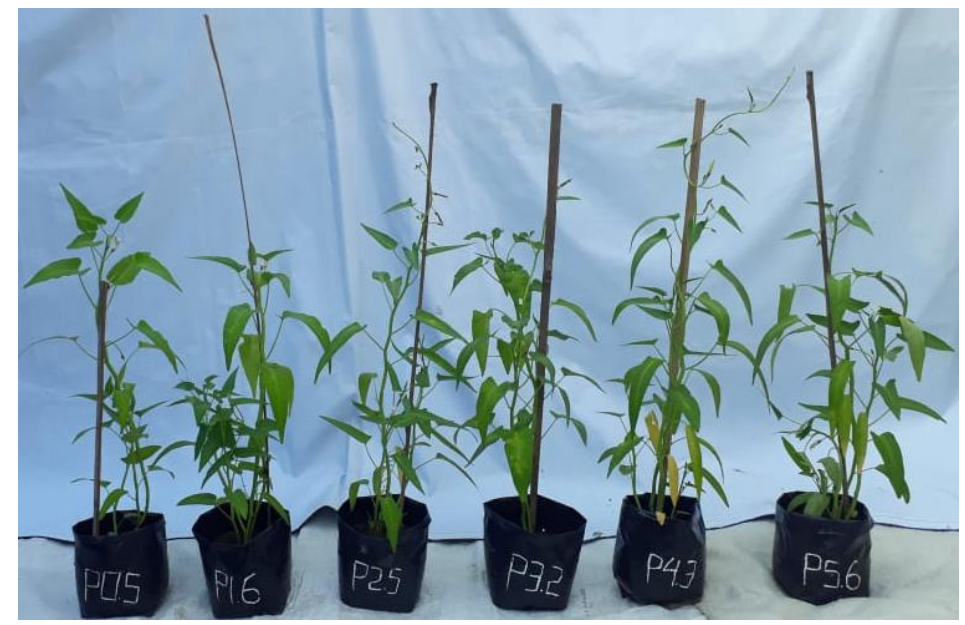

Figure 2. The observation results of the stem height of Ipomoea reptans Poir. 
The number of leaves is a parameter to indicate the size of the photosynthate produced by a plant which is related to the value of plant productivity. The results of counting the number of leaves of ground spinach (Ipomoea reptans Poir.) are presented in Figure 3.

Figure 3. shows that the highest number of leaves of land spinach (Ipomoea reptans Poir.) is shown at a concentration of $8 \%$, which is 62 pieces. Increased vegetative growth is supported because of the presence of nitrogen nutrients needed in leaf formation and high auxin activity, so that it affects cell division and enlargement such as in leaf cells. As a result, the number of leaves will increase (Handriatni, 2010).

Leaf area is an important parameter for determining the rate of photosynthesis of a plant (Hariodamar \& Santoso, 2018). The results of leaf area measurements of ground water spinach (Ipomoea reptans Poir.) are presented in Figure 4.

According to Larasati et al. (2018) the more leaves on a plant, the greater the resulting leaf area.
The finding research of this study showed that the number of leaves and leaf area in treatment $8 \%$ had superior values compared to other treatments. According to Hariodamar \& Santoso, (2018) that the larger the leaf area, sunlight can be absorbed optimally to increase the rate of photosynthesis. If the rate of photosynthesis is optimal, there will be an increase in photosynthate which is translocated to the vegetative parts of the plant to form new organs. Nitrogen functions as a form of chlorophyll which plays an important role in the process of photosynthesis. The higher the nitrogen application (until the optimum limit), the amount of chlorophyll formed will increase (Adil, 2006). Increasing the amount of chlorophyll causes the rate of photosynthesis to increase so that plant growth is faster and maximum. The results of photosynthesis are used for the growth of plant organs, where the larger plant organs are formed, the more moisture the plant can bind to others (Koryati, 2004).

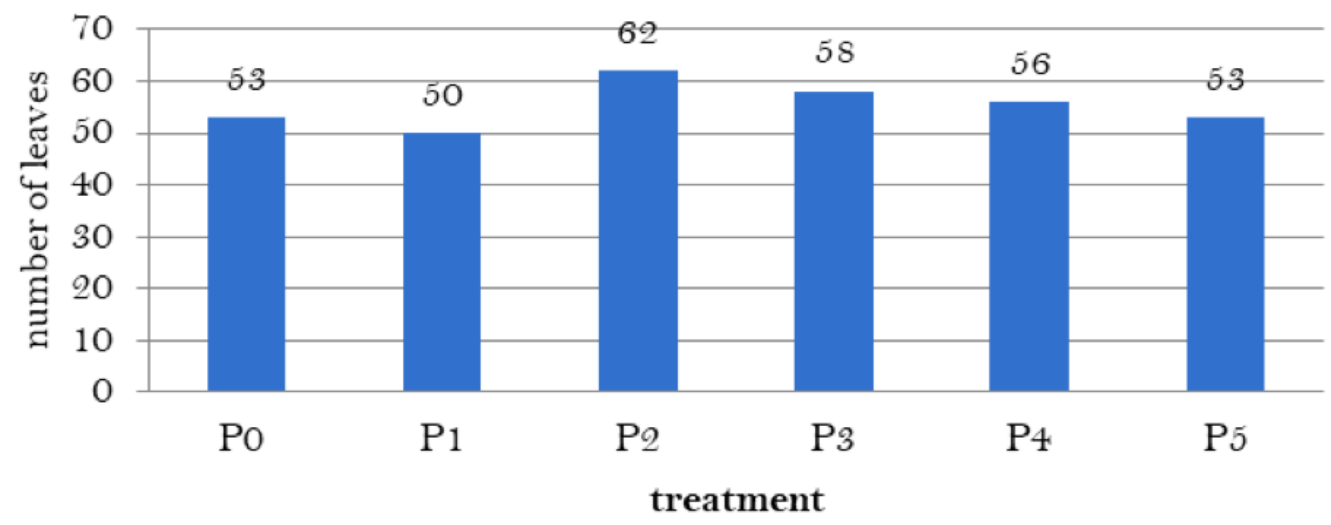

Figure 3. Number of leaves of ground water spinach in the $6^{\text {th }}$ week Po: Control (without fertilizer) P1: Concentration 4\%; P2: Concentration 8\% P3: Concentration 12\%; P4: Concentration 16\% P5: Concentration $20 \%$

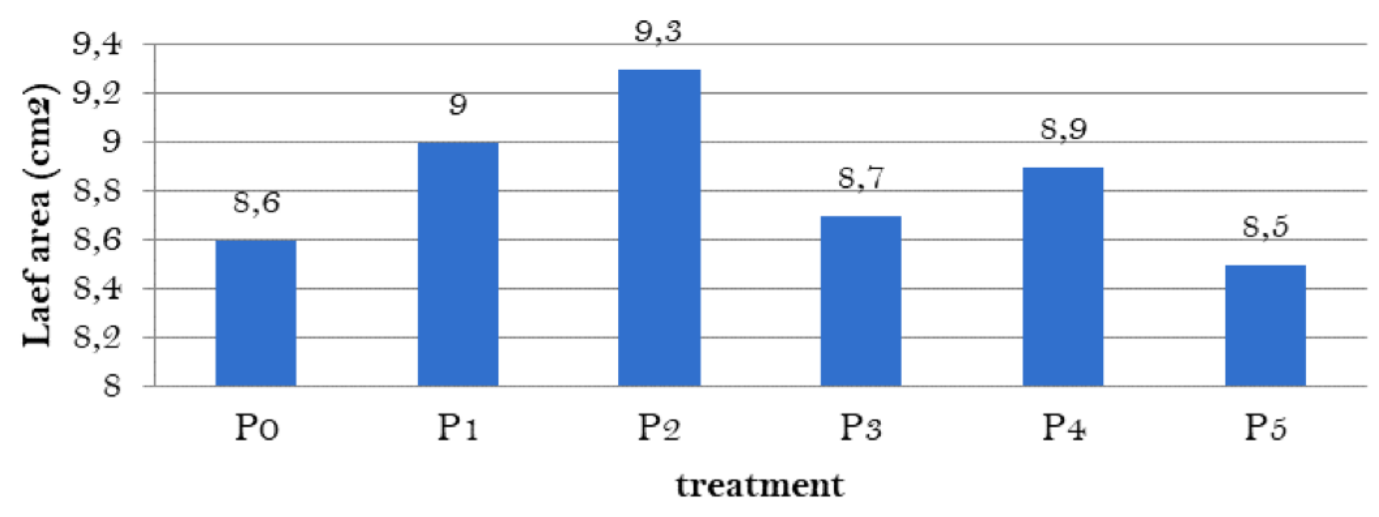

Figure 4. Leaf area of ground water spinach week 3; Po: Control (without fertilizer); P1: concentration 4\%; $\mathrm{P} 2$ : concentration $8 \% \mathrm{P} 3$ : concentration 12\%; P4: concentration 16\% P5: concentration 20\% 


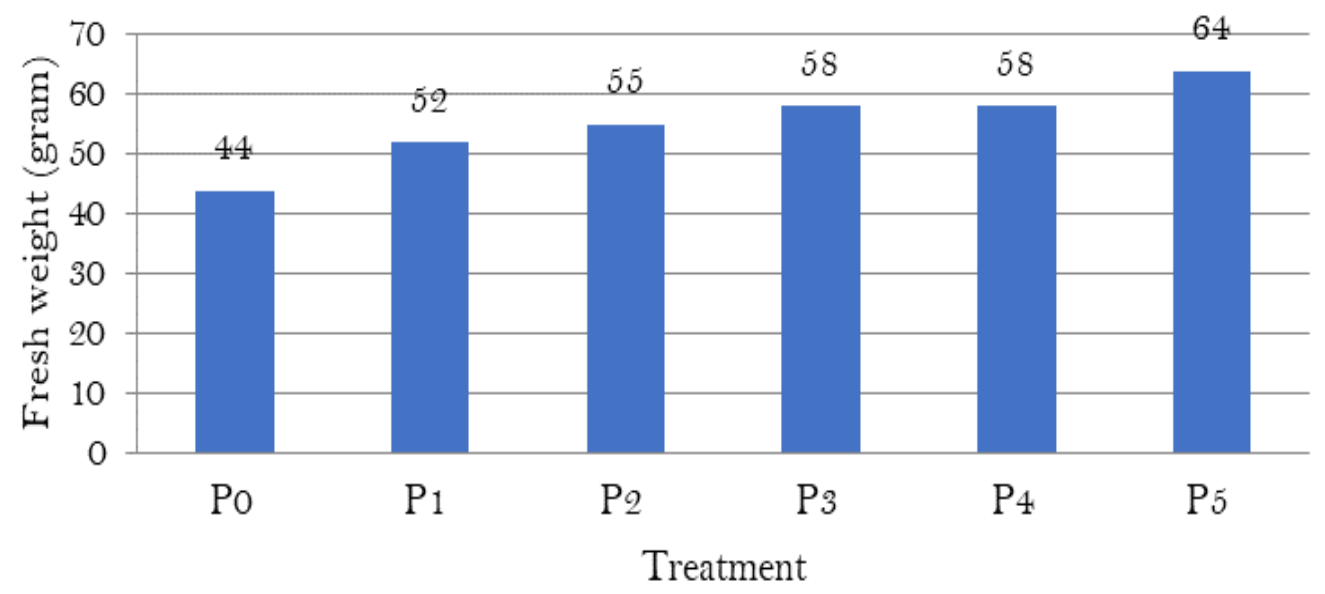

Figure 5. Fresh weight of ground water spinach week 6; Po: Control (without fertilizer); P1: Concentration 4\%; P2: Concentration 8\% P3: Concentration 12\%; P4: Concentration 16\% P5: Concentration 20\%

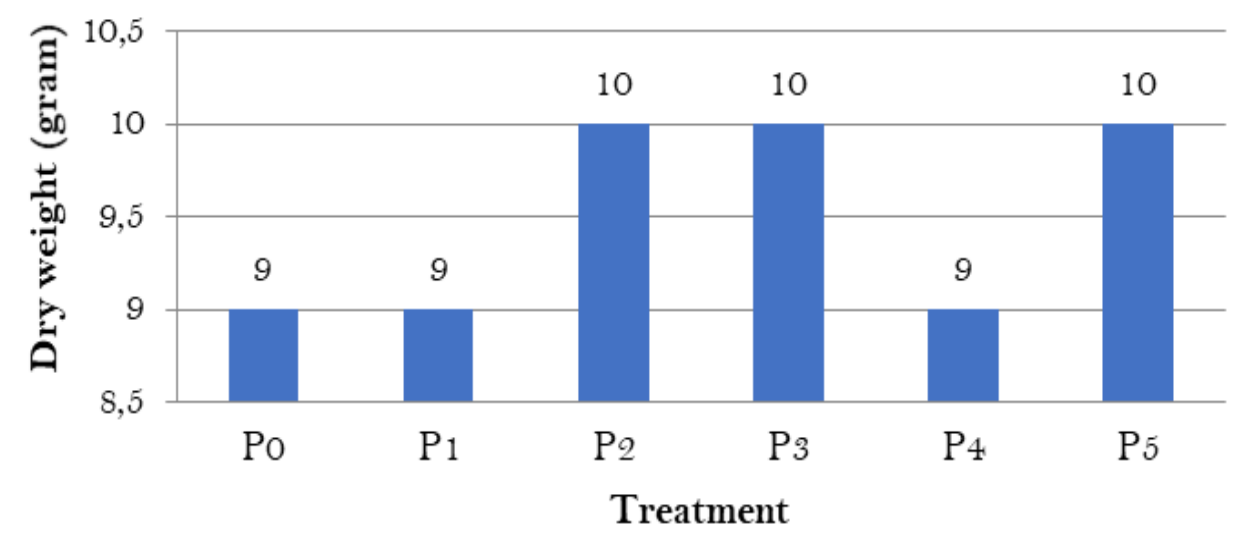

Figure 6. Dry weight of ground water spinach week 6; Po: Control (without fertilizer); P1: concentration $4 \%$; P2: concentration $8 \%$ P 3: concentration 12\%; P4: concentration $16 \%$ P 5 : concentration $20 \%$

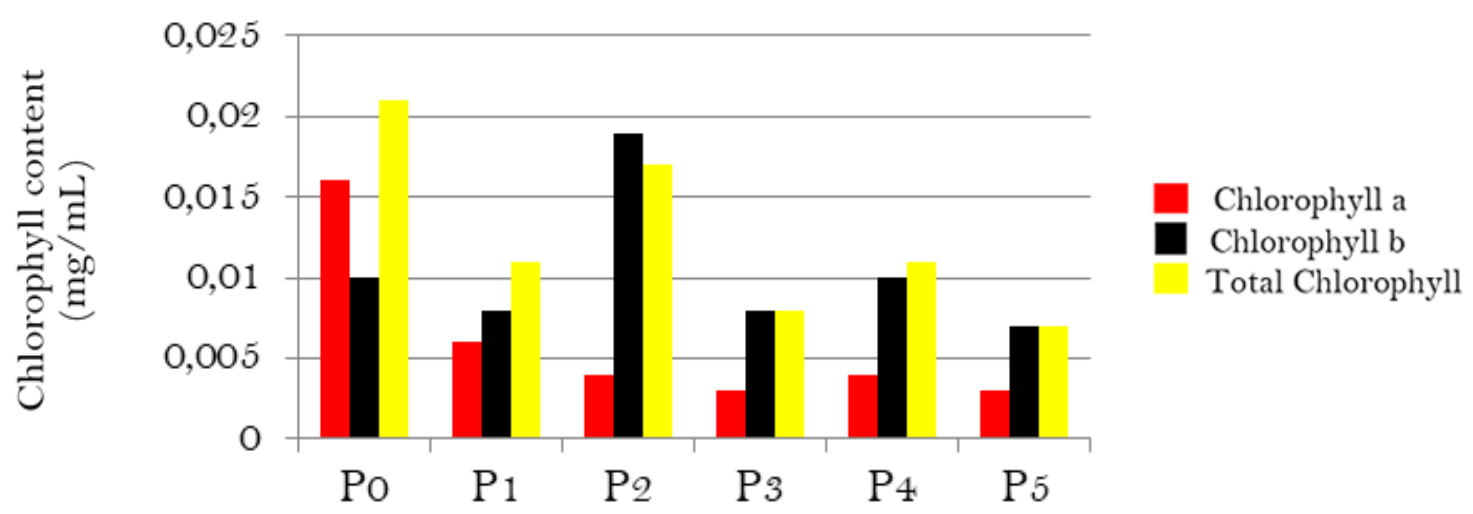

Figure 7. Chlorophyll test of ground water spinach: Po: Control (without fertilizer); $\mathrm{P} 1$ : concentration $4 \%$; 2 : concentration $8 \% \mathrm{P} 3$ : concentration $12 \%$; $\mathrm{P} 4$ : concentration $16 \%$; P 5: concentration $20 \%$ 
Wet weight is one of the parameters to determine the growth of a plant, namely by measuring the biomass and water produced by the plant. The wet weight of Ipomoea reptans Poir. Which is the highest was produced at a concentration of $20 \%$ (Figure 5). According to Haryoto (2009), the availability of water at the roots of the Ipomoea reptans poir plant of 89.7 grams. The water will be used as photosynthetic material and supported by the presence of nutrients from the additional treatment of liquid organic fertilizers so that it can increase biomass. Nitrous nutrients play an important role in spurring the development of plant organs such as roots, so that plants are able to absorb more water and nutrients. $\mathrm{N}$ and $\mathrm{K}$ nutrients support plant height increase because $K$ helps metabolize carbohydrates and accelerates the growth of meristematic tissue (Nyakpa et al., 1998). An increase in the absorption of these nutrients will increase the photosynthetic activity and affect the increase in wet weight.

Dry weight is one of the parameters to determine plant production. Ipomoea reptans Poir. dry weight results presented in Figure 6. Figure 6. shows that there is an increase in the dry weight of kale plants with the application of liquid organic fertilizer with apu-apu. The dry weight in each treatment decreased when compared to the results of the wet weight weighing. This occurs because the water content in the plants has been lost due to heating in the drying process, so that what is left is the results of photosynthesis such as accumulation of carbohydrates, proteins, vitamins and other organic materials (Rahmah et al., 2014). Based on the Anova test results (Table 2), the concentration of liquid organic fertilizer apu-apu did not have a different effect. This can be due to the low nutrient content in the liquid organic fertilizer so that it has not been able to fulfill the elements $\mathrm{N}, \mathrm{P}, \mathrm{K}$ in the soil so that the accumulation of photosynthate between treatments is not different. Plant dry weight is influenced by nutrient content absorbed during the growth process (Satria et al., 2015). Based on Table 3, the humidity of the air during the observation tends to be low, with low humidity in the air it will spur the transpiration rate. Thus, the water stored in the tissue will be reduced so that photosynthetic output will also be slower and the results of photosynthesis are also less.

Chlorophyll content test is a parameter to determine the main productivity of a plant. The main productivity in terms of the rate of production of organic matter ( $\mathrm{C}=$ carbon $)$ through photosynthetic reactions. The results of the chlorophyll test for Ipomoea reptans Poir. was presented in Figure 8.

Figure 8 shows that the highest chlorophyll in the control treatment (without fertilizer). This can be due to the lack of nitrogen contained in the planting medium will affect the amount of chlorophyll formed for the photosynthesis process (Wenno \& Sinay, 2019). The highest chlorophyll b was given $8 \%$ treatment. According to Wenno et al. (2019), leaves that are supplied with nitrogen will form leaves that have wider leaf blades with a higher chlorophyll content. The highest total chlorophyll in control (without fertilizer). The presence of the element nitrogen will increase the green leaf color (chlorophyll). The formation of chlorophyll requires sufficient and balanced amounts of nitrogen, because nitrogen is the main component in the preparation of chlorophyll (Alamsjah et al., 2019)

The results of ANOVA analysis followed by Duncan's test showed that the treatment with a concentration of $8 \%$ showed a significant difference in the vegetative growth of land spinach (Ipomoea reptans Poir.) On the parameters of the number of leaves, leaf area, wet weight and plant height (Table $2)$.

Table 2. Observations on the growth of Ipomoea reptans Poir. at 6 MST

\begin{tabular}{|c|c|c|c|c|c|}
\hline \multirow[b]{2}{*}{ Treatment } & \multicolumn{5}{|c|}{ Parameter } \\
\hline & $\begin{array}{c}\text { Number of leaves } \\
\text { (unit) }\end{array}$ & $\begin{array}{c}\text { Plant height } \\
(\mathrm{cm})\end{array}$ & $\begin{array}{c}\text { Leaf area } \\
\left(\mathrm{cm}^{2}\right)\end{array}$ & $\begin{array}{c}\text { Fresh } \\
\text { weight }(\mathrm{g})\end{array}$ & $\begin{array}{c}\text { Dry } \\
\text { weight (g) }\end{array}$ \\
\hline $\mathrm{Po}(\mathrm{O} \%)$ & $53^{\mathrm{ab}}$ & $60.0^{\mathrm{b}}$ & $8.6^{\mathrm{a}}$ & $44^{\mathrm{a}}$ & 9 \\
\hline $\mathrm{P}_{1}(4 \%)$ & $5 \mathrm{O}^{\mathrm{a}}$ & $58.4^{\mathrm{ab}}$ & $9.0^{\mathrm{b}}$ & $52^{\mathrm{b}}$ & 9 \\
\hline $\mathrm{P}_{2}(8 \%)$ & $62^{\mathrm{c}}$ & $49.4^{\mathrm{a}}$ & $9.3^{\mathrm{c}}$ & $55^{\mathrm{c}}$ & 10 \\
\hline P3 $(12 \%)$ & $58^{\mathrm{b}}$ & $50.7^{\mathrm{a}}$ & $8.7^{\mathrm{ab}}$ & $58^{\mathrm{c}}$ & 10 \\
\hline $\mathrm{P} 4(16 \%)$ & $56^{\mathrm{b}}$ & $112.8^{\mathrm{c}}$ & $8.9^{\mathrm{b}}$ & $58^{\mathrm{c}}$ & 9 \\
\hline P5 (20\%) & $53^{\mathrm{ab}}$ & $63.8^{\mathrm{b}}$ & $8.5^{\mathrm{a}}$ & $64^{\mathrm{c}}$ & 10 \\
\hline
\end{tabular}

Note: Different superscripts in the same column have significantly different treatment $(\mathrm{p}<0.05)$ 
Table 3. Observations of environmental factors in Ipomoea reptans Poir.

\begin{tabular}{ll}
\hline Factors & Average \\
\hline Temperature $\left({ }^{\circ} \mathrm{C}\right)$ & 38,7 \\
Humidity $(\%)$ & 46,6 \\
Light intensity (lux) & $610,9-679,6$ \\
\hline
\end{tabular}

Environmental factors observed in this study included temperature, humidity and light intensity. Observation of environmental factors aims to determine the effect of environmental factors on the growth of Ipomoea reptans Poir., because plants have growing requirements so that they can grow optimally. Observations on environmental factors in Ipomoea reptans Poir. was presented in Table 3.

The results of temperature observations are not suitable according to (Utami \& Rachmawati, 2016), Ipomoea reptans Poir. have growing conditions with a temperature range of $28-33^{\circ} \mathrm{C}$. The role of temperature on plant growth is very important because high and low temperatures affect enzyme activity (Mulyono, 2019). The results of the humidity observation showed that the humidity was lower than the optimal humidity as a condition for growing Ipomoea reptans Poir. namely 80-90\%. According to Aulia et al. (2019), water spinach requires a minimum of 20,000 lux of light. Plants are better able to grow well in slightly dim light intensity than full light. This condition is favorable for leaf size and stem lengthening of the plant.

\section{CONCLUSION}

It can be concluded that the application of liquid organic fertilizer apu-apu (Pistia stratiotes L.) increases the growth of land spinach (Ipomoea reptans Poir.). The optimum concentration of liquid organic fertilizer apu-apu (Pistia stratiotes L.) for the growth of land spinach (Ipomoea reptans Poir.) is $8 \%$ capable of having an effect on the growth of leaf number, leaf area, and wet weight.

\section{REFERENCES}

Adil, W. H. (2006). Effect of three different nitrogen fertilizers on several vegetable crops. Biodiversitas, Journal of Biological Diversity, 7(1), 77-80. https://doi.org/10.13057/biodiv/do70119.

Alamsjah, W., Tjahjaningsih, W., \& Pratiwi, A.W. (2019). Pengaruh Kombinasi Pupuk NPK dan TSP terhadap Pertumbuhan, Kadar Air dan Klorofil A Gracilaria verrucosa. Jurnal Ilmiah Perikanan dan Kelautan, 1(1), 103. http://dx.doi.org/10.20473/jipk.v1i1.11705.

Amik, K., \& Hardini, D. (2014). Kajian Beberapa Dekomposer terhadap Kecepatan Dekomposisi Sampah Rumah Tangga Amik. Buana Sains, 14(2), 7989.

Ari Handriatni, S. (2010). Upaya Peningkatan Produksi Tanaman Kangkung Darat Ipomea reptans Poir dengan Pemangkasan dan Pemberian Pupuk N Di Lahan
Pantai. Pena Akuatika, 1(1), 1-11. http://dx.doi.org/10.31941/penaakuatika.v1i1.258.

Aulia, S., Ansar, A., \& Putra, G. M. D. (2019). Pengaruh Intensitas Cahaya Lampu dan Lama Penyinaran Terhadap Pertumbuhan Tanaman Kangkung (Ipomea reptans Poir) Pada Sistem Hidroponik Indoor. Jurnal Ilmiah Rekayasa Pertanian dan Biosistem, 7(1), 43-51. https://doi.org/10.29303/jrpb.v7i1.100

Baroroh, F., Handayanto, E., Irawanto, R., (2018). Fitoremediasi Air Tercemar Tembaga $(\mathrm{Cu})$ Mengguanakan Salvinia Molesta dan Pistia stratiotes Serta Pengaruhnya terhadap Pertumbuhan Tanaman Brassica Rapa Phytoremedation of Copper $(\mathrm{Cu})$ Contaminated Water Using Salvinia molesta and Pistia stratiotes and Its. Jurnal Tanah Dan Sumberdaya Lahan, 5(1), 2549-9793. https://jtsl.ub.ac.id/index.php/jtsl/article/view/188.

Djuariah, D. 1997. Evaluasi plasma nutfah kangkung di dataran medium Rancaekek. Jurnal Hortikultura 7(3):756-762.

Edi, S dan A. Yusri. 2009. Kandungan gizi dan Manfaat Kangkung. Jambi: Balai Pengkajian Teknologi Pertanian.

Utami, B. L., \& Rachmawati, U. (2016). Pengaruh Pemberian Pupuk Organik Pada Media Tanah yang Mengandung Timbal $(\mathrm{Pb})$ terhadap Pertumbuhan Kangkung Darat (Ipomoea reptans Poir.). Jurnal Biologi Udayana, 20(1), 6-10. https://ojs.unud.ac.id/index.php/BIO/article/view/2 4943.

Hariodamar, H., \& Santoso, M. (2018). Pengaruh Pemberian Pupuk Nitrogen Terhadap Pertumbuhan Dan Hasil Dua Varietas Tanaman Sawi (Brassica Juncea L .) Jurnal Produksi Tanaman, 6(9), 2133-2141. http://protan.studentjournal.ub.ac.id/index.php/prot an/article/view/889.

Haryoto. 2009. Bertanam Kangkung Raksasa di Pekarangan. 1ed. Yogyakarta: Kanisius. hlm: 12-13.

Hayati, E., A.H. Ahmad, dan C.T. Rahman. 2010. Respon Jagung Manis (Zea mays, Sacharata SHOUT) terhadap Penggunaan Mulsa dan Pupuk Organik. Agrista, 14(1), 21-24. http://jurnal.unsyiah.ac.id/agrista/article/view/691.

Indriani, Y.H. 2002. Membuat Kompos secara Kilat. Cetakan 4. Jakarta: Penebar Swadaya.

Jumirah, I., Jati, A. W. N., \& Yulianti, L. I. M. (2018). Kualitas Pupuk Cair Organik Dengan Kombinasi Limbah Ampas Jamu dan Limbah Ikan. Biota, 3(2), 53-61. https://doi.org/10.24002/biota.v3i2.1893.

Koryati, T. (2004). Pengaruh Penggunaan Mulsa dan Pemupukan Urea terhadap Pertumbuhan dan Produksi Cabai Merah (Capsicum annum L .). Jurnal Penelitian Bidang Ilmu Pertanian, 2(April), 13-16. http://repository.usu.ac.id/bitstream/handle/ 123456 789/15495/kpt-apr2004\%20\%285\%29.pdf? sequence $=1$ \&isAllowed $=y$.

Kusandriyani, Y., \& Luthfy, N. (2016). Karakterisasi Plasma Nutfah Kangkung. Buletin Plasma Nutfah, 12(1), 30-33. http://dx.doi.org/10.2 1082/blpn.v 12n 1.2006.p30-33.

Larasati, E. D., Euis Elih Nurlaelih, \& Sitawati. (2018). Tanggap Pertumbuhan dan Warna Daun Pucuk Merah (Syzygium oleana) pada Dosis Pupuk MgSO4 
Dan Tingkat Naungan. Jurnal Produksi Tanaman, 6(9), 2094-2102.

http://protan.studentjournal.ub.ac.id/index.php/prot an/article/view/884.

Lingga, P dan Marsono. 2006. Petunjuk Penggunaan Pupuk. Jakarta: Penebar Swadaya.

Mulyono, D. (2019). Pengaruh Intensitas Naungan Dalam Aklimatisasi Pertumbuhan Planlet Gaharu (Aquilaria Beccariana). Jurnal Sains Dan Teknologi Indonesia, 16(1),

28-33. https://doi.org/10.29122/jsti.v16i1.3404.

Nyakpa, Y. M., A. M. Lubis, M. A. Pulung, A. G. Amrah, A. Munawar, G. B. Hong, dan N. Hakim. 1998. Kesuburan Tanah. Universitas Lampung. Lampung.

Noviyanti, S. 2019. Agar Petani Tak Ketergantungan Pupuk Anorganik. http://kilaskementerian.kompas.com.

Nur, T., Noor, A. R., \& Elma, M. (2016). Tangga Dengan Penambahan Biioaktivator Em 4 (Effective Microorganisms). Konversi, $5(2), \quad 5-12$. http://dx.doi.org/10.20527/k.v5i2.4766.

Oviyanti, F., \& Hidayah, N. (2016). Pengaruh Pemberian Pupuk Organik Cair Daun Gamal (Gliricidia Sepium (Jacq.) Kunth Ex Walp.) terhadap Pertumbuhan Tanaman Sawi (Brassica juncea L.). Jurnal Biota, 2(1), 61-67.

http://jurnal.radenfatah.ac.id/index.php/biota/article /view/531.

Puspadewi, R., Adirestuti, P., \& Anggraeni, G. (2011). Aktivitas Metabolit Bakteri Lactobacillus plantarum dan Perannya Dalam Menjaga Kesehatan Saluran Pencernaan. Konferensi Nasional Sains Dasar Dan Aplikasinya, June 2011, 1-11.
Rahmah, A., Izzati, M., \& Parman, S. (2014). Pengaruh Pupuk Organik Cair Berbahan Dasar Limbah Sawi Putih (Brassica Chinensis L.) Terhadap Pertumbuhan Tanaman Jagung Manis. Buletin Anatomi dan Fisiologi, 22(1), https://doi.org/10.14710/baf.v22i1.7810

Rijal, M. (2014). P. Stratiotes. Jurnal Biology Science E Education, 3(2), 94-105.

Satria, N.; Wardati; \& Khoiri, M. A. (2015). Pengaruh Pemberian Kompos Tandan Kosong Kelapa Sawit dan Pupuk NPK terhadap Pertumbuhan Bibit Tanaman Gaharu (Aquilaria Malaccencis). Jom Faperta, 2(1), 114. https://jom.unri.ac.id/index.php/JOMFAPERTA/ar ticle/view/7286.

Sulaeman,Y., Maswar, Erfandi, \& Deddy. (2016). Pengaruh Kombinasi Pupuk Organik dan Anorganik terhadap Sifat Kimia Tanah, dan Hasil Tanaman Jagung di Lahan Kering Masam. Jurnal Pengkajian dan Pengembangan Teknologi Pertanian, 20(1),1-12. http://dx.doi.org/10.2 1082/jpptp.v20n 1.2017.p1-12.

Wenno, S. J., Sinay, H., Program, A., Pendidikan, S., Program, D., \& Pendidikan, S. (2019). Kadar Klorofil Daun Pakcoy (Brassica Chinensis L.) Setelah Perlakuan Pupuk Kandang dan Ampas Tahu Sebagai Bahan Ajar Mata Kuliah Fisiologi Tumbuhan. Biopendix, Jurnal Biologi, Pendidikan dan Terapan, 3(2), 130-139. https://doi.org/10.30598/biopendixvol5issue2page 13 o-139. 